\title{
How to Achieve a Better Budget for the European Union?
}

\section{CEPS Working Document No. 289/ April 2008}

\author{
Daniel Gros
}

\section{Abstract}

In recent decades the EU has widened and deepened to such an extent that it now deals in almost all areas of policy-making. I ts budget, however, has barely changed over this period. It thus needs to be radically reformed if it is to reflect the priorities of an expanding and deepening Union. Over $40 \%$ of spending still supports agriculture, a declining sector; spending for research and innovation, recognised as the main driving force of productivity growth, is too low, and there is no room in the budget for the new public goods of domestic and external security that the public demands. However, the budget is determined through an inter-governmental negotiation in which no entity defends the over-arching European interest since all countries (rationally) care only about their 'net balance'.

Radical changes in budgetary decision-making procedures are no longer possible since the Reform Treaty, now in the ratification process, essentially cemented a procedure that combines the primacy of national interests with a very strong status quo bias. The latter arises because in the absence of a unanimous agreement on new priorities the old budget automatically continues to apply. If this status quo bias cannot be broken major reforms become virtually impossible.

The forthcoming mid-term review of the budget should be used to achieve political agreement on breaking the status quo bias by introducing 'sunset' clauses, which stipulate that major spending programmes will be discontinued after a certain period of time unless their usefulness can be ascertained and a new agreement reached allowing their continuation. Movement in the right direction can thus start immediately, even within the present legal framework, especially if Parliament uses its influence to push for a better allocation of expenditure.

CEPS Working Documents are intended to give an indication of work being conducted within CEPS research programmes and to stimulate reactions from other experts in the field. Unless otherwise indicated, the views expressed are attributable only to the author in a personal capacity and not to any institution with which s/ he is associated.

ISBN-13: 978-92-9079-783-8

Available for free downloading from the CEPS website (http:/ / www.ceps.eu)

(c) Daniel Gros, 2008 


\section{Contents}

Introduction: The need for a fundamental rethink of the EU budget ........................................ 1

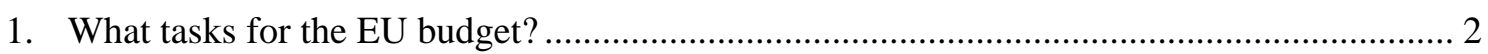

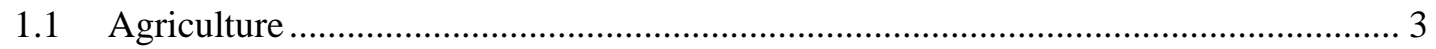

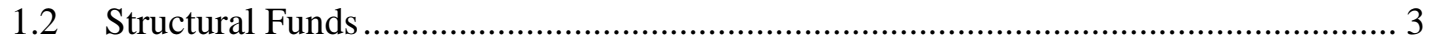

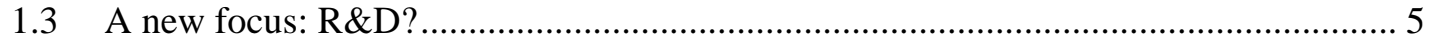

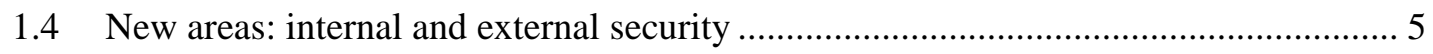

1.5 Provision of European public goods as the guiding principle for the EU budget......... 6

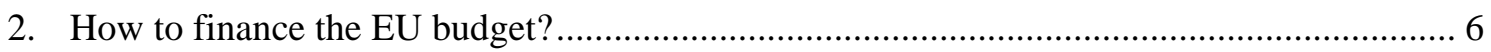

3. The key problem in decision-making: Net balances as the focal point ................................. 10

3.1 Overhauling decision-making: Still possible? .............................................................. 13

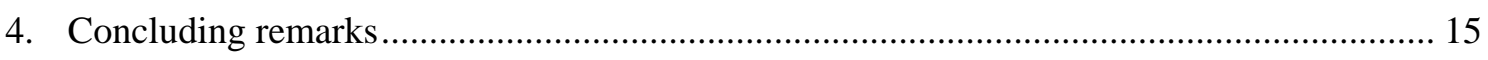

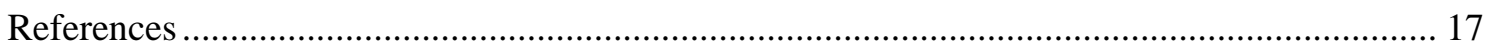

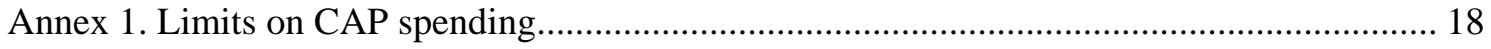

Annex 2. Budgetary provisions in the Reform Treaty ……....................................................... 20 


\section{How to ACHIEVE A BETTER Budget FOR THE EUROPEAN UNION? DANIEL GROS*}

\section{Introduction: The need for a fundamental rethink of the EU budget}

The EU budget does not reflect its main tasks and policy goals. Support for agriculture, a declining sector with few prospects for employment and growth, still represents $40 \%$ of total expenditures; funds for education, research and infrastructure comprise less than one-third; allocations to the new common foreign policy, defence, internal security, immigration and citizen rights is negligible, despite strong demand by the public for greater Union involvement in these areas.

The current composition of spending is the result of historical accidents. The key driving force behind the two items that now dominate the budget - agriculture and regional aid - was the perception in a grey [“darker”?] past that Europe needed to ensure its own food supply and, in the 1980s and 1990s, that poorer member countries needed to be bribed to accept the internal market and monetary union. The main legacy of the 'founding' compromises on agriculture and Structural Funds is that the budget is basically seen as a vehicle for the redistribution of money between member states, rather than a tool for fostering common goals.

National interests are thus framed exclusively in terms of what national treasuries have to pay to, and what farmers and regions at home are likely to receive from, the EU budget. But this means that in the inter-governmental negotiations that determine the budget no voice will defend overall EU interests. For any individual member state the return from defending an EUwide, encompassing interest is negligible compared to the advantage it can obtain from a change in the budget that might lead to lower overall efficiency but more money for its own citizens or regional governments.

Thus negotiations on the budget are mainly of an inter-governmental nature, and tend to concentrate on the net balances resulting from national contributions to the budget and funds received by each country under the various spending programmes.

European citizens have no clear perception of the total cost of the Union and the overall benefits of common action financed by the budget. But the few direct beneficiaries (mainly farmers) are well aware of budgetary transfers in their favour and place pressure on their government to preserve them indefinitely.

The budget's increasing detachment from the Union's own objectives is sustained by decisionmaking procedures that entail strong rigidity in budgetary allocations. Decisions on the resource ceiling and the allocation of spending among the main budget headings are made in the context of the multi-year financial perspectives (MYFP), which by established practice cover seven years; these decisions are taken by the Council and require unanimity. Moreover, more often than not, decisions on agriculture and other multi-year programmes (e.g. research) are made independently of budgetary procedures and with reference to a different time frame.

\footnotetext{
* Director of the Centre for European Policy Studies, Brussels. Many thanks to Jorge Núñez Ferrer for comments and suggestions. This paper is based in part on previous joint work with Stefano Micossi. This paper was first prepared for the Conference on Public Finances in the EU, organised by the Bureau of European Policy Advisers (BEPA), European Commission, Brussels, 3-4 April 2008.
} 
The European Parliament has formal powers only in the yearly budgetary procedure, after the ceilings for spending among the main headings have been established according to the MYFP; at this stage, reshuffling resources is close to impossible. Therefore, it comes as no surprise that budgetary allocations are only a pale reflection of the Union's evolving policy goals.

The current MYFP 2007-13 represents a repeat of the past. It had already been prejudged by the Franco-German compromise, in 2002, to block further reform of agricultural policies until 2013. Moreover, the decision to limit appropriation commitments to 1\% of GDP shifted most of the adjustment burden onto Structural Funds. Thus the urgently needed shift of resources in favour of research, education (badly needed to spur economic growth), and the new requirements for foreign policy, defence and internal security did not take place.

The opportunity to engage in a fundamental rethink of the EU budget was missed in 2005-06. Will the impending mid-term review be another missed opportunity?

Radical changes are needed both in budget content - its revenues and spending programmes and decision-making procedures to endow the Union with an effective instrument to foster its policy goals. The latter is a precondition for the former. Only with a new procedure, one in which European interests dominate, will the Union obtain a better budget.

Citizens must be made fully aware of the European budget's costs and benefit in order to be able to decide on what they are willing to spare for the Union. The European Parliament, which is the citizens' direct representative in European institutions, must have the main say in budgetary decisions, with appropriate safeguards against excessive spending. The debate on these issues should be (re-)opened immediately.

It is not possible to change the formal decision-making procedure before the new Reform Treaty enters into force, but the nature of the budgetary process could be radically changed if a political agreement can be reached on what is needed.

This contribution starts by briefly reviewing what Union policies should be financed by the common budget. It then turns to how decision-making procedures should be changed to make the budget an expression of European, rather than national, interests and an effective instrument in support of Union policies. In the conclusion, I sketch out a few measures that could improve budgetary decision-making in the long run.

\section{What tasks for the EU budget?}

What tasks should the EU perform, and does it require a much larger budget to perform them? Historically, the EU's key purpose has been to open markets and integrate national economies. Market integration has been largely achieved for manufactured products, but not for services, where much still needs to be done. However, fostering market integration is mainly a regulatory function and does not require substantial spending at EU level. Strengthening market surveillance and enforcement at the national level is more important in this respect than a large budget.

The final step in economic integration - the adoption of a common currency - has also already been taken. However, the approach that underlies the Maastricht Treaty also implies that the monetary union can be managed without a large central budget, since fiscal policy has clearly been left in member state hands. We doubt that there are great gains to be reaped from an enhanced coordination of national fiscal policies for anti-cyclical purposes; but even if this activity were entrusted to the Union, it would not seem to require a large budget. ${ }^{1}$

\footnotetext{
${ }^{1}$ Cyclical stabilisation could be undertaken simply by coordinating national budgets, as advocated by many authors. Asymmetric shocks could be dealt with by establishing a common insurance fund to provide appropriate (temporary) financial assistance to countries hit by them.
} 
This leaves two principal justifications for EU spending: re-distribution and providing European-wide public goods. It might be useful to briefly recapitulate how the most important expenditure areas should be considered under these two criteria.

\subsection{Agriculture}

There is no need to discuss at length the common agricultural policy (CAP). There is broad agreement that this policy does little to foster cohesion, as most subsidies are actually paid to richer (more efficient) farmers in richer member states. (There is vast literature on this; see, for example, Ferrer (2007).) It is also clear that member states are in a better position than the Union to execute this agricultural policy, which basically entails interpersonal redistribution and local development.

Agricultural spending is a major distorting factor in the EU economy and a distinct obstacle to the Lisbon agenda's implementation. The Union's new members are likely to suffer most from such spending, since the CAP affects relative prices and incomes in favour of agriculture and thus discourages investment in industry and services, where the potential for technical progress and productivity increases is much greater. Moreover, the Union's external actions related to development aid are crippled politically by barriers to agricultural trade maintained because of the CAP.

Historically, agricultural spending has been a major source of tension between member states, owing to the skewed distribution of payments and their impact on countries' net balances vis-àvis the EU. Payments to French farmers alone make up almost one-quarter of total CAP spending; together, French, German and Italian farmers take away about one-half, or onequarter of the entire EU budget. Phasing out the CAP would also help to eliminate the UK rebate, which introduced the concept of special treatment of one member state - a concept that is now spreading and making the budget ever more opaque.

\subsection{Structural Funds}

When the internal market programme was launched in the early 1990s and plans for EMU began to take shape, it was argued that the EU needed to compensate poorer member states for agreeing to these steps, leading to a large increase in structural fund support for the Union's poorer countries and regions.

The implicit assumption was that poorer member states took a risk by exposing their weaker economies to the full competition resulting from the internal market and by agreeing to plans for a common currency, which would require budgetary efforts on their part. Experience has shown, however, that poorer countries can actually benefit from the internal market and the euro's introduction. Moreover, empirical evidence suggesting that EU Structural Funds have, on average, accelerated the economic convergence of poor regions is weak. Nevertheless, this result hides extreme cases of remarkable success and utter failure, indicating that the way Structural Funds are spent and the economic context in which they are injected significantly influence results. Similarly, the opposite EMU experiences of, for example, Ireland and Portugal suggests that membership in the euro area can be very beneficial provided national policy-making is appropriate.

On the whole the Structural Funds thus seem to make economic sense. Moreover, they represent a visible commitment to the value of economic and social cohesion within the Union, underpinned by Treaty recognition. This concrete expression of solidarity between member states and their people is also necessary for an effective functioning of the Union's political institutions. 
Table 1. Appropriations for commitments (annual average) in the multi-year financial perspectives (1988-2013)

\begin{tabular}{|c|c|c|c|c|c|c|c|c|}
\hline \multirow[b]{2}{*}{ Appropriations for commitments } & \multicolumn{2}{|c|}{$\begin{array}{c}\text { DELORS I }^{\mathrm{a}} \\
1988-92\end{array}$} & \multicolumn{2}{|c|}{$\begin{array}{c}\text { DELORS II }^{\mathrm{b}} \\
1993-99\end{array}$} & \multicolumn{2}{|c|}{$\begin{array}{c}\text { AGENDA } 2000^{\circ} \\
2000-06\end{array}$} & \multicolumn{2}{|c|}{$\begin{array}{c}\text { NEW MYFP } \\
2007-13\end{array}$} \\
\hline & Mio ECU & $\% \mathrm{EU}$ & Mio ECU & $\% \mathrm{EU}$ & Mio $€^{*}$ & $\% \mathrm{EU}$ & Mio $€$ & \% EU \\
\hline 1. Agriculture & $28,440^{* *}$ & 58.1 & 36,503 & 48.2 & 42,534 & 46.1 & & \\
\hline$C A P$ & $28,440^{* *}$ & 58.1 & & & 38,196 & 41.4 & 43,011 & 29.4 \\
\hline Rural development and other & & & & & 4,339 & 4.7 & 14,797 & 10.1 \\
\hline 2. Structural operations & 10,628 & 21.7 & 25,200 & 33.3 & 30,430 & 33.0 & & \\
\hline Cohesion Fund & & & 2,164 & 2.9 & 12,104 & 13.1 & $49,273 * * *$ & 33.6 \\
\hline Structural Funds & & & 23,035 & 30.4 & 27,859 & 30.2 & & \\
\hline 3. Internal policies & 1,862 & 3.8 & 4,512 & 6.0 & 6,261 & 6.8 & 21,609 & 14.8 \\
\hline Competitiveness for growth and employment & & & & & & & 18,965 & 13.0 \\
\hline Citizenship, freedom, security and justice & & & & & & & 2,644 & 1.8 \\
\hline 4. External actions & 2,498 & 5.1 & 5,200 & 6.9 & 8,100 & 8.8 & 13,656 & 9.3 \\
\hline External actions & 2,498 & 5.1 & 4,629 & 6.1 & 4,580 & 5.0 & & \\
\hline Emergency aid & & & 271 & 0.4 & 200 & 0.2 & & \\
\hline Loan guarantees & & & 300 & 0.4 & 200 & 0.2 & & \\
\hline Pre-accession aid & & & & & 3120 & 3.4 & & \\
\hline 5. Administration & 4,540 & 9.3 & 3,640 & 4.8 & 4,809 & 5.2 & 4,089 & 2.8 \\
\hline 6. Monetary reserves & 1,000 & 2.0 & 643 & 0.8 & 179 & 0.2 & & \\
\hline Total & 48,968 & 100 & 75,698 & 100 & 92,313 & 100 & 146,434 & 100 \\
\hline Appropriations for payments & 46,936 & & 72,177 & & 91,643 & & 132,671 & \\
\hline Appropriations for payments (\% of GNP) & 1.15 & & 1.22 & & 1.07 & & GNI 1.14 & \\
\hline Own resource ceiling (\% of GNP) & 1.18 & & 1.23 & & 1.27 & & GNI 1.24 & \\
\hline
\end{tabular}

${ }^{a}$ Heading 3 includes multi-year policies (R\&D, IMP); Heading 4 included "other non-compulsory policies".

${ }^{\mathrm{b}}$ Heading 3 includes R\&D, TENs, environment and the functioning of the internal market.

c Internal policies includes training, youth culture, etc.; energy, nuclear and environment; consumer protection, internal market, etc.; research and technological development, other internal policies.

$* 1$ ecu $=1$ euro. ${ }^{* *}$ Allocation for EAGGF, section guarantee only. *** Cohesion and Solidarity funds included.

Sources: European Commission and author's own estimates. 
Accordingly, while financing under this heading should continue to exist, it should also be clear that support cannot last forever and should be phased out as countries enjoy rising standards of living as a result of integration. To this end, eligibility has been based on an objective and transparent criterion (per capita GDP less than $75 \%$ of the EU average) for Objective One regions. However, special and ad hoc arrangements, introduced in the spirit of 'juste retour', are also being extended in this area to render it less transparent.

In the coming years the amount of financing required under this heading will decline for recipients in the EU-15, reflecting higher incomes per capita, but it will have to increase to support institution-building, infrastructure and environmental upgrading in new member states.

As for policies specifically designed to increase growth, the Sapir Report (Sapir et al. (2003)) has argued that a new heading should be created in the European budget, with substantial resources for trans-European infrastructure networks and research. The Commission proposal for the new MYFP 2007-13 included this argument, but it was subsequently squashed by the European Council, which found it easier to agree on maintaining spending on agriculture rather than increase spending on the future.

\subsection{A new focus: R\&D?}

The one field that typically serves the public good and whose benefits extend far beyond national boundaries is research and development (R\&D). Moreover, recent research suggests that $R \& D$ is a key growth factor for countries aspiring to become 'the most productive economy'. This combination of ideas was behind the Lisbon agenda's emphasis on the 'knowledge society'. There can be little doubt that a substantial increase in funds for research in the EU budget is justified. More money is needed for public and private research centres and networks of excellence in all sciences, and to greatly enhance the mobility of researchers. ${ }^{2}$

However, increased EU funding alone cannot bring European R\&D to the level required to allow the Union to realise its goals about the 'knowledge society'. Over 95\% of all R\&D spending in Europe remains at the national level. Moreover, as shown by many authors (see also Gros (2004)), R\&D spending in Europe yields a much lower return in terms of commercially exploitable ideas (patents) than in the US. The main challenge is to make European research spending more effective; the key step to take toward this end is opening up the market for research funds. Not only EU R\&D funding, but also national funding should be opened up to Union-wide competition, including all national science support programmes.

\subsection{New areas: internal and external security}

Next, the Union can, and must, take up other new functions ('public goods') on a much larger scale.

Indeed, the Union is clearly moving beyond the scope of a pure "economic union". Over the last few decades it has been steadily adding elements of political integration by moving into such areas as internal and external security and foreign policy.

\footnotetext{
${ }^{2}$ Of course, EU funds could be spent more productively. The present system - whereby priorities in the Framework Programmes are the result of political negotiations in the Council and funds are disbursed by the European Commission - should be abandoned, because it leads to a wasteful multiplication of priorities and fragmentation of grants. Moreover, a new 'European Science Agency', shaped on the example of the US National Science Foundation, should be established to foster scientific excellence, identify priority research areas and ensure the highest standards of project selection.
} 
With the free movement of people within the EU, the need for a common approach to guarding external borders and combating international crime has become evident. While only a few first timid steps have been taken in building what is called the European Common Area of Freedom, Security and Justice, it is clear that over time common institutions will be required. The sheer force of numbers ${ }^{3}$ strongly suggests that a European FBI, a European Border Guard and a European prosecutor might well be operating by the time the next MYFP are discussed in the 2010s.

Moreover, the economies of scale in the field of external security have been vividly illustrated in recent conflicts, from Kosovo to Iraq. When member states do not coordinate their policies and pool their means, the Union does not count. Progress has been even slower in this area, but many signs indicate that it is speeding up.

It is ironic that the EU spends the least in these areas when survey after survey of public opinion confirms strong citizen support for greater Union involvement.

\subsection{Provision of European public goods as the guiding principle for the EU budget}

This brief discussion suggests one guiding principle for the EU budget: expenditure at the EU level is appropriate mainly to safeguard a European public good. Over time, the EU budget structure should reflect this simple principle. There is no justification for spending a major part of the EU's scarce resources over decades on a declining industry such as agriculture. Substantial resources will have to continue to be devoted to promoting income convergence, which is needed to preserve the political cohesion that allows the EU to work efficiently. The Union's role in fostering productivity, growth and employment should increase, with a strong focus on human capital and research.

Substantial resources will also be needed for the Union to fulfil its potential role in the world and to provide strong security within and beyond its borders.

Altogether, this does not seem to require a major increase in the Union's resources. One percent of aggregate GDP/GNI seems to provide adequate margins for the Union to effectively perform the tasks that have been described - provided that we are able to spend money where it is needed rather than yield to the demands of organised interest groups.

\section{How to finance the EU budget?}

At present the Union's budget draws its resources from customs and agricultural levies (traditional resources), a VAT resource levied on a 'notional' harmonised VAT base ${ }^{4}$ and a 'fourth' resource based on gross national income (GNI). The last plays a residual role: its amount is determined ex-post so as to fill the gap between actual spending and the revenues flowing from traditional and VAT resources. This residual is then allocated among member states in proportion to their share in the Union's GNI and is paid by each member state out of its national budget. As seen in Table 2, by 2005 this GNI resource represented three-quarters of total revenues.

\footnotetext{
${ }^{3}$ In an EU-27, a matrix of bilateral liaison officers among national policy agencies has over 700 different points of contact.

${ }^{4}$ The base is calculated on the basis of national VAT receipts and capped at $50 \%$ of each member GNI so as to correct for the VAT's allegedly regressive nature. In practice, when capping applies, this resource is turned de facto into a GNI-based resource. Since 2002 the VAT call rate for the Union is $0.5 \%$.
} 
Table 2. EU-15 own resources, 1996-2005

\begin{tabular}{|l|c|c|c|}
\hline Percentage share of revenues: & 1996 & 2000 & 2005 \\
\cline { 2 - 4 } Traditional & 19.1 & 17.4 & 11.4 \\
VAT & 51.3 & 39.9 & 14.1 \\
GNP/GNI & 29.6 & 42.7 & 74.5 \\
\hline Total own resources (€ billion) & 71.1 & 88 & 108.5 \\
\hline
\end{tabular}

Source: European Commission.

The fact that the GNI resource dominates revenues is in flat contradiction with EC Treaty Art. 269 (old numbering), which prescribes that "the Union shall be financed wholly from own resources". By contrast, under the present system the vast majority of Union resources comes from well-identified contributions from national budgets, which member states inevitably consider 'their money' and want to compare with 'their' receipts from the EU budget. The focus of policy-making is usually the likes of Table 3, which provides the elements of member state average annual net balances for 2000-03.

Table 3's "payments to EU budget" column represents actual payments by national treasuries to the EU budget. One concrete step to lessen this focus on the impact on national budgets is to rescind on the revenue side all links between national treasuries and the EU budget. The cost to maintain the EU should fall directly and visibly on its citizens as a whole.

However, we must also bear in mind that, (as also stipulated under Art. 10 of the EC Treaty (old numbering)), Community programmes and activities within individual member states are implemented by their public administrations. It is not possible, nor indeed desirable, to create a separate EU tax administration.

Therefore, the solution is to rely on national tax systems that 'dedicate' to Europe the revenue from one particular tax. Efficiency and equity require that this tax is levied on a broad base and harmonised at the EU level at a moderate rate. A broad base also entails that special allowances on grounds of horizontal equity can be kept to a minimum, as the overall burden would continue to amount to a small share of GDP/GNI.

Since the aim is to make the EU's costs as transparent as possible to European citizens, it is tempting to jump to the conclusion that the best way to achieve this is to add a 'Euro tax' to the personal income tax return bill that most citizens have to submit every year. However, this solution is not feasible in practice since it would lead to a highly unequal distribution of the burden, given the large differences in national definitions of taxable income. As a result, the yield of personal income taxation varies widely across member states, with low values of around $3-4 \%$ of GDP (e.g. Slovakia and Poland) and peaks of over 25\% of GDP (e.g. Denmark).

Narrowness and lack of harmonisation of the base also seem to rule out, as a feasible alternative, a surcharge on corporate income. The proposal of taking money for the EU from central bank reserves does not meet the test of visibility and accountability vis-à-vis European citizens.

Most of these difficulties do not arise with the VAT. Its base has been reasonably harmonised; the rates do not differ as greatly as do those for personal income taxation; the differences in yields are relatively minor, ranging from a low of around 6\% of GDP in countries like Italy and Spain to a maximum of 9\% of GDP in Hungary and Sweden (see Table 4). 
Table 3. EU-15 allocated expenditure, payments to EU budget and budgetary balances by member state (annual averages 2000-03)

\begin{tabular}{|c|c|c|c|c|c|c|c|c|c|c|c|}
\hline \multirow[b]{4}{*}{ Belgium } & \multicolumn{6}{|c|}{ EU allocated expenditure } & \multirow{2}{*}{\multicolumn{2}{|c|}{$\begin{array}{c}\text { Payments to EU budget }^{\mathrm{d}} \\
\text { Total }\end{array}$}} & \multicolumn{2}{|c|}{ Balances } & \multirow{3}{*}{$\begin{array}{l}\text { GNI per head } \\
\text { Th. } €(2003)\end{array}$} \\
\hline & \multicolumn{2}{|c|}{ Total $^{\mathrm{a}}$} & \multicolumn{2}{|c|}{ Agriculture $^{\mathrm{b}}$} & \multicolumn{2}{|c|}{ Structural Operations $^{\mathrm{c}}$} & & & & & \\
\hline & Mio $€$ & \% EU TOT & Mio $€$ & $\%$ EU AG & Mio $€$ & $\%$ EU SO & Mio $€$ & $\%$ EU TOT & Mio $€$ & $\%$ GNP-GNI ${ }^{\mathrm{e}}$ & \\
\hline & $1,814.3$ & 2.48 & 967.4 & 2.28 & 225.8 & 0.89 & $2,312.4$ & 3.16 & -498.0 & -0.19 & 26.5 \\
\hline Denmark & $1,449.5$ & 1.98 & $1,217.1$ & 2.86 & 83.4 & 0.33 & $1,540.8$ & 2.11 & -91.3 & -0.05 & 35.0 \\
\hline Germany & $10,611.5$ & 14.52 & $6,056.6$ & 14.26 & $3,651.5$ & 14.35 & $17,593.4$ & 24.05 & $-6,981.9$ & -0.34 & 25.9 \\
\hline Greece & $5,200.0$ & 7.12 & $2,652.8$ & 6.24 & $2,370.1$ & 9.32 & $1,273.9$ & 1.74 & $3,926.1$ & 2.95 & 13.8 \\
\hline Spain & $13,883.6$ & 19.00 & $6,032.1$ & 14.20 & $7,531.7$ & 29.60 & 6,209.2 & 8.49 & $7,674.4$ & 1.16 & 17.4 \\
\hline France & $12,109.8$ & 16.57 & $9,620.4$ & 22.65 & $1,813.4$ & 7.13 & $13,822.4$ & 18.89 & $-1,712.6$ & -0.11 & 26.4 \\
\hline Ireland & $2,526.7$ & 3.46 & $1,739.1$ & 4.09 & 704.3 & 2.77 & 1,010.1 & 1.38 & $1,516.6$ & 1.46 & 28.1 \\
\hline Italy & $9,497.5$ & 13.00 & $5,370.2$ & 12.64 & $3,557.3$ & 13.98 & $10,605.2$ & 14.50 & $-1,107.7$ & -0.09 & 22.5 \\
\hline Luxembourg & 122.3 & 0.17 & 33.7 & 0.08 & 7.7 & 0.03 & 198.7 & 0.27 & -76.4 & -0.38 & 44.8 \\
\hline Netherlands & $1,836.8$ & 2.51 & $1,282.1$ & 3.02 & 244.5 & 0.96 & $3,820.5$ & 5.22 & $-1,983.8$ & -0.47 & 28.1 \\
\hline Austria & $1,467.2$ & 2.01 & $1,072.9$ & 2.53 & 238.4 & 0.94 & $1,853.1$ & 2.53 & -385.9 & -0.18 & 27.1 \\
\hline Portugal & 3,697.1 & 5.06 & 789.2 & 1.86 & $2,776.8$ & 10.91 & $1,162.3$ & 1.59 & $2,534.8$ & 2.07 & 12.6 \\
\hline Finland & $1,220.4$ & 1.67 & 814.6 & 1.92 & 294.2 & 1.16 & $1,195.5$ & 1.63 & 24.9 & 0.03 & 27.7 \\
\hline Sweden & $1,229.2$ & 1.68 & 815.6 & 1.92 & 250.4 & 0.98 & $2,160.9$ & 2.95 & -931.7 & -0.38 & 29.4 \\
\hline UK & $6,416.6$ & 8.78 & $4,019.4$ & 9.46 & $1,692.9$ & 6.65 & 8,395.6 & 11.48 & $-1,979.0$ & -0.04 & 28.8 \\
\hline EU-15 & $73,082.4$ & 100 & $42,482.9$ & 100 & $25,442.2$ & 100 & $73,154.1$ & 100 & -71.7 & & 24.7 \\
\hline
\end{tabular}

${ }^{\text {a }}$ External and administrative expenditures are excluded.

${ }^{\mathrm{b}}$ Direct aid, export refunds, storage, rural development, other.

c Structural Funds, other specific structural operations, Cohesion Funds.

${ }^{\mathrm{d}}$ VAT and GNI-based own resources adjusted payments (including UK rebate). It is not MS actual payments but the allocation key of these payments. This allocation key is applied only to total allocated operating expenditure in order for budgetary balances to add up to zero. Total payments are consequently set to equal total EU operating allocated expenditure.

${ }^{\mathrm{e}}$ Data in \% of GNP-GNI are calculated on ESA79 GNP data for 2000-01 and ESA95 GNI data for 2002-03. The concept of GNP has been replaced by the GNI in the EU budgetary and own resources area from 2002 in accordance with Council Decision No. 2000/597.

Source: European Commission, September 2004. 
Table 4. Private consumption and VAT (\% of GDP, 2003)

\begin{tabular}{|l|c|c|}
\hline & Private consumption/GDP & VAT/GDP \\
\hline EU-25 & 58.3 & 7.0 \\
EU-15 & 58.2 & 7.0 \\
Belgium & 54.5 & 7.0 \\
Czech Republic & 50.9 & 6.5 \\
Denmark & 47.2 & 9.7 \\
Germany & 59.0 & 6.5 \\
Estonia & 56.6 & 8.9 \\
Greece & 67.2 & 7.8 \\
Spain & 57.8 & 6.3 \\
France & 55.5 & 7.2 \\
Ireland & 45.2 & 7.2 \\
Italy & 60.4 & 6.1 \\
Latvia & 63.0 & 7.3 \\
Lithuania & 64.9 & 6.9 \\
Luxembourg & 41.9 & 6.5 \\
Hungary & 54.7 & 9.1 \\
Malta & 60.8 & 7.1 \\
The Netherlands & 48.4 & 7.7 \\
Austria & 56.1 & 7.9 \\
Poland & 66.0 & 8.2 \\
Portugal & 62.3 & 8.5 \\
Slovenia & 54.4 & 8.9 \\
Slovakia & 55.3 & 6.8 \\
Finland & 52.3 & 8.6 \\
Sweden & 48.7 & 9.2 \\
UK & 65.5 & 7.1 \\
\hline Sourc: E & &
\end{tabular}

Source: Eurostat, 2005.

A flat rate of around 2\% throughout the Union should be sufficient to finance a EU budget of about the present size (1\% of GDP). Receipts for all purchases subject to VAT would show the amount paid to the Union, thus making citizens aware of their contribution. VAT receipts pertaining to the Union would be transferred automatically and continually to Union accounts, as they accrue to member state VAT offices, and would no longer be shown on national budgets. The burden on national budgets would change only marginally, since lower receipts on account of VAT would be largely offset by lower payments to the EU budget under the GNI resource.

Under this proposal, ideally the EU budget would be covered by only one tax, with clear benefits of transparency and visibility. However, Art. 268 requires the Union budget to always be "in balance". Therefore, some mechanisms for ex-post adjustment of revenues in light of actual spending, such as the existing GNI resource, have to be maintained. Such mechanisms, however, should amount to no more than a small shock absorber to make up for unforeseen differences between actual revenues and expenditures, with net excesses and shortfalls of spending shared on the basis of shares in overall GNI.

An EU VAT surcharge would lead to a reasonably even distribution of the burden, and would not necessarily be regressive. A traditional view holds that poorer countries have higher consumption as a proportion of income, and hence a relatively larger VAT base. However, the 
data in Table 4 indicate that among countries with high VAT revenues one finds both rich (Sweden) and poor (Hungary); the same applies to countries with low VAT revenues in proportion to GDP (e.g. Spain, a cohesion country, and Italy, with GDP per capita above the EU average).

Introducing a European VAT surcharge would not immediately eliminate the perspective of governments that the EU budget's most important aspect is the national "net balance", because governments would probably consider that their citizens' contributions to the EU budget should simply be considered relative to the benefits their citizens and enterprises receive. But the amounts contributed to the Union would no longer appear on national budgets, and EU citizens would have a direct indicator of how much they pay for common policies. ${ }^{5}$

\section{The key problem in decision-making: net balances as the focal point}

The lengthy negotiations that preceded agreement on the current financial framework once again illustrated the extent to which net (im)balances have become the focal point for almost all decision-making participants, but particularly the Council. ${ }^{6}$

Interestingly, within the EU-15, net imbalances have tended to shrink over time, reflecting reduced structural support, owing to the convergence of income per capita, and lower payments under the CAP (Table 5). Moreover, Figure 1 (taken from Gros and Micossi (2005)) shows that between 1993 and 2003, the relationship between net balances and differences in per capita income within the EU-15 has grown less steep, which appears to be mainly a consequence of the reduction in agricultural payments. This indicates that member states have become less willing to remain net payers even though the integration process has continued, increasing benefits for all members, for example, through the internal market's creation, but also through the additional security, both internal and external, that should be the result of cooperation within the CFSP and JHA domain.

\footnotetext{
${ }^{5}$ As an aside, one might note that in general it does not matter whether one uses GDP or GNP as the base for a country's ability to contribute to the EU (and eligibility for Structural Funds) since for most countries the difference between GDP and GNP is minor, less than $1 \%$. The one important exception is Ireland, where GDP is about $20 \%$ higher than GNP, which is attributable to a large proportion of the value added produced in Ireland (measured by GDP) originating in enterprises owned by foreign firms. This is a consequence of the large amount of FDI Ireland has received in recent decades. Some new member countries might soon experience a similar phenomenon since they are also receiving a sustained large inflow of FDI.

${ }^{6}$ The elimination of the UK rebate, without any other mechanism taking its place, would be another important contribution to breaking the link between national treasuries and the EU budget. But would this be appropriate in light of the large net negative balance that would then arise for the UK? The straight answer (see Ferrer (2007)) is that - once the CAP is phased out - a correction mechanism for net imbalances is no longer needed. The reason is two-fold. First, with the CAP out of the way, spending under the EU budget could legitimately be considered a genuine expression of public preference for European public goods. Second, with a European VAT surcharge financing the whole budget, the cost of European public goods would be borne by all countries and their citizens, roughly in proportion to their consumption spending and incomes.
} 
Table 5. EU-15 net balances 1993-2003

(averages over stated periods as a percentage of GDP/GNI)

\begin{tabular}{|l|c|c|c|}
\hline Country & $1993-96$ & $1996-99$ & $2000-03$ \\
\hline Belgium & 0.03 & -0.17 & -0.19 \\
Denmark & 0.31 & 0.05 & -0.05 \\
Germany & -0.65 & -0.55 & -0.34 \\
Greece & 4.50 & 3.92 & 2.95 \\
Spain & 1.13 & 1.28 & 1.16 \\
France & -0.14 & -0.11 & -0.11 \\
Ireland & 5.40 & 4.06 & 1.46 \\
Italy & -0.18 & -0.15 & -0.09 \\
Luxembourg & -0.54 & -0.47 & -0.38 \\
The Netherlands & -0.25 & -0.49 & -0.47 \\
Austria & -0.35 & -0.36 & -0.16 \\
Portugal & 3.17 & 3.09 & 2.07 \\
Finland & -0.06 & -0.09 & 0.03 \\
Sweden & -0.41 & -0.48 & -0.38 \\
UK & -0.13 & -0.19 & -0.04 \\
\hline Standard deviation & 1.94 & 1.66 & 1.04 \\
\hline
\end{tabular}

Source: European Commission.

The problem was aggravated in the 1980s by the decision to grant the UK a 'rebate' in order to correct an otherwise unbearably large net contribution by that country, which has a small agricultural sector and shows limited eligibility for structural support. The UK rebate and the bitter negotiations that preceded it strengthened the perception of the EU budget as a vehicle for inter-governmental transfers, reflecting countries' negotiating strength. Over time, the rebate's fairness has come under increasing criticism, since other member states with lower per capita income accepted higher net payments to the EU budget, as a ratio to their GNI (i.e. Belgium, Germany, the Netherlands and Sweden).

On this score, enlargement made matters worse, since the new member states attract an increasing share of funds at the very time when the willingness to finance the EU budget by net contributors is sharply diminished, while traditional recipients of Structural Funds drag their feet to delay their inevitable reduction. For example, Ireland, one of the member states with the highest GDP per capita, continues to receive structural fund support and will continue to have a positive net balance (and have a higher GDP per capita than all net contributors) even by 2013.

It is unlikely that this state of affairs will end any time soon since, for any individual member state, the return from defending an EU-wide, encompassing interest is dwarfed by the advantage it can obtain from a budget change in its own favour, even if this leads to lower overall efficiency.

This perverse incentive structure applies even to the largest member state, Germany, which accounts for a little less than a quarter of the budget and EU population. For Germany the return from efficiently spending one euro on some EU-wide interest would be around 25 cents, only a quarter of the return of any one euro spent in Germany. Thus, if the German government has the choice between spending more on a European public good and spending more on something that benefits mainly German interests, it will always choose the latter. 
Figure 1. Net balances and GNP/GNI per head in 1993 and 2003 (in thousands of ecu and euro), scatter plot and linear regression

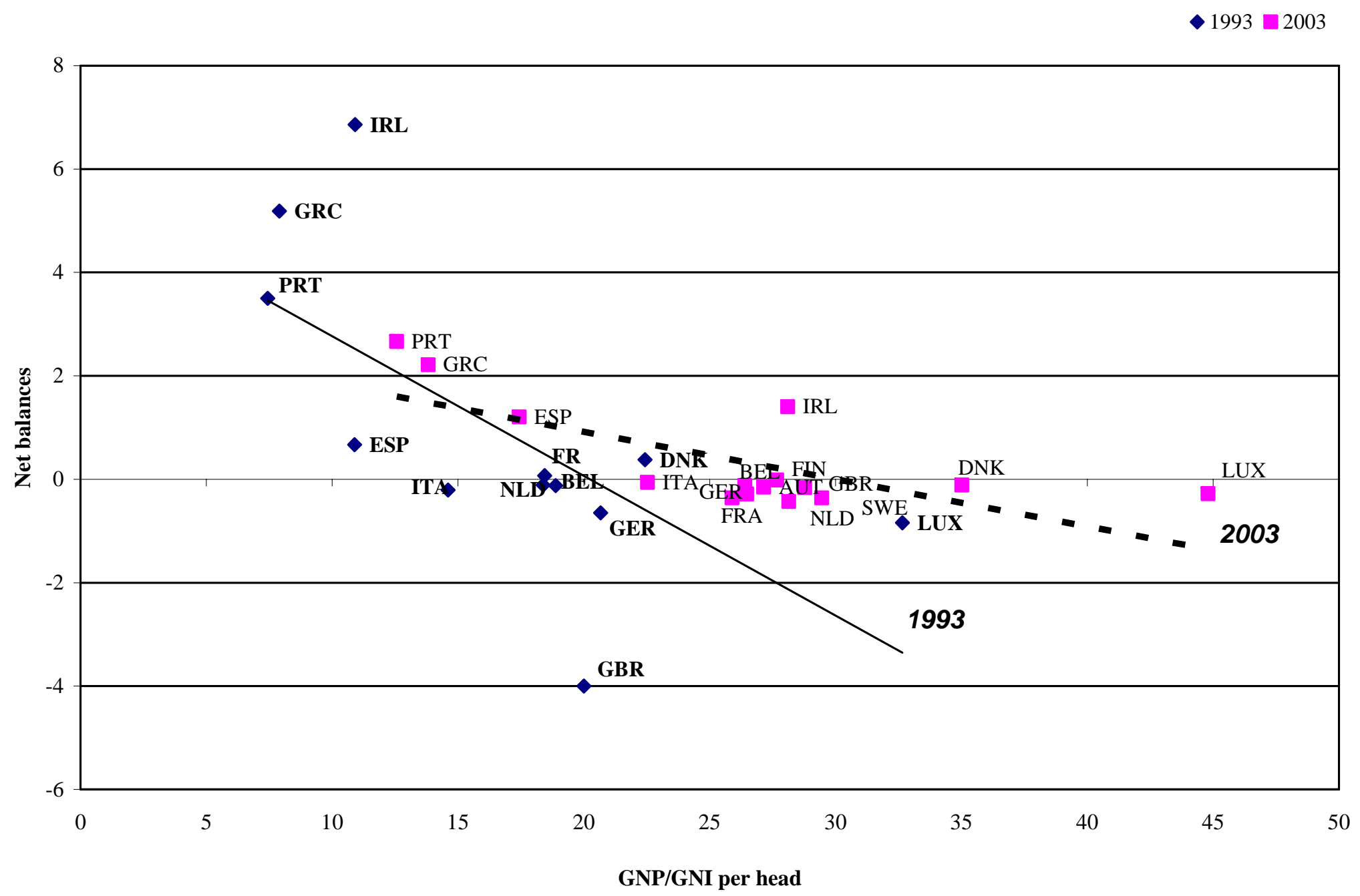

Source: European Commission, 2003 and 2004. 
The same reasoning applies with even more force to member states whose EU budget stake is smaller. Moreover, the problem grows worse because with each successive enlargement the budget stakes of individual member states become smaller. For example, the largest new member country, Poland, has a share in the EU budget of less than $5 \%$ and a population share below $10 \%$.

Therefore, it is not surprising that new member states concentrate on diverting EU transfers to their own citizens while preserving the present budget structure. ${ }^{7}$ The skewed distribution of payments to member states under the CAP and the structural fund programmes only aggravates the problem.

\subsection{Overhauling decision-making: still possible?}

Decision-making procedures play a central role in preserving the budget's anachronistic structure and should therefore be changed. However, this will be difficult.

The practice so far was based on the fact that the Treaty had explicit provisions for deciding the system of own resources and the yearly budget, but not the MYFP, which is where all key budgetary decisions are made. The MYFP's key role is obvious in Figure 2, which shows MYFP values and actual annual budgets since 1988 for the two major budget items (CAP and Structural Funds). It is apparent that annual budgets adhere to values determined in the multiyear frameworks. (With one difference between CAP and Structural Funds: over the last 14 years Agricultural spending was more often above than below target, whereas the opposite is true for Structural Funds. The last two MYFP specified that one-third of the budget should be spent on Structural Funds, but in reality it was on average about 8\% less.)

Based on a Commission proposal and after consulting the Parliament, the Council decides, by unanimous vote, on the own resources system. Member states then recommend the decision's adoption "in accordance to their constitutional requirements" (Art. 269). This paper's proposal to convert to a true system of own resources by dedicating a share of VAT receipts to the EU budget would thus not require a change in the Treaty. Given that it would also not imply the creation of a new tax, it would probably also not require a referendum.

The Council (by qualified majority) and Parliament (by absolute majority) together make yearly budget decisions (Art. 272); the Council has the final say on "compulsory" expenditures, ${ }^{8}$ which notably includes the CAP, and Parliament has the final say on the rest of the budget. The budget must cover all expenses of EU institutions (universality) and always be balanced. The Commission prepares the preliminary draft budget, but subsequently has no formal role in the decision. Nevertheless, it is responsible for executing the budget.

\footnotetext{
${ }^{7}$ The political importance of the contribution to the EU is heightened in countries with a federal fiscal system. For example, in Germany federal government revenues amount only to around $20 \%$ of GDP. This implies that a contribution to the EU equivalent to 1\% of GDP accounts for 5\% of Germany's federal government revenues. In countries where central government revenues are a much higher proportion of GDP, the relative importance to the central government of its contribution to the EU budget is smaller, even with similar contributions as a share of GDP.

${ }^{8}$ Compulsory expenditures are only obliquely referred to in Art. 272, para. 9, of the EC Treaty: "A maximum rate of increase...shall be fixed annually for the total expenditure other than that necessarily resulting from this Treaty or from acts adopted in accordance therewith". The precise classification of expenditures falling within this category can be found in annexes to the inter-institutional agreements.
} 
Figure 2. CAP and Structural Funds as share of total EU spending compared to targets in MYFP (Delors I, II and Agenda 2000)

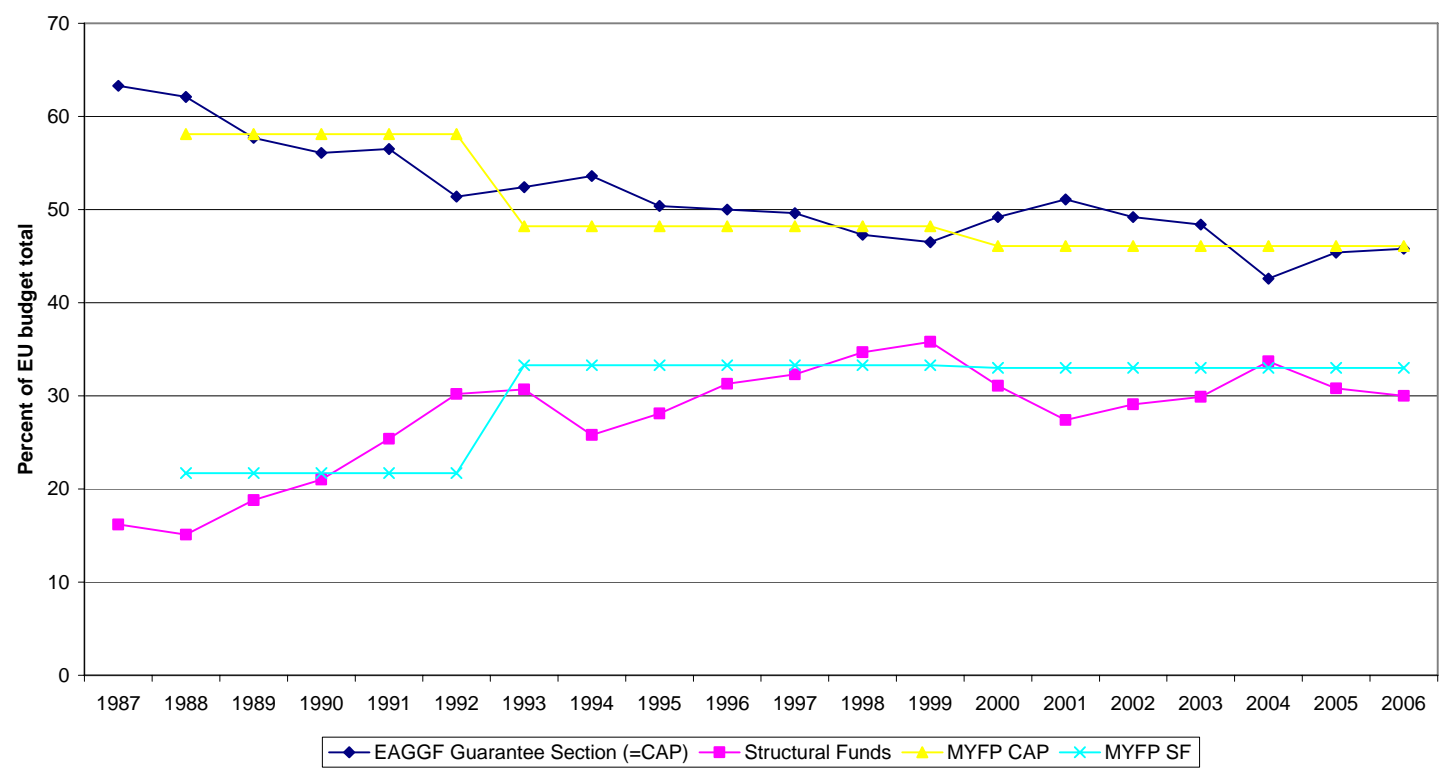

The MYFP system was agreed to at the end of the 1980s, after years of bitter contests between the Council and Parliament that had led to paralysis and in two instances (1979 and 1984) to Parliament's rejection of the budget. Under this new system, the Council fixes by unanimity the MYFP for a period of between five and seven years, which includes annual ceilings for total resources and the main spending headings. The Commission prepares the initial proposal, but the Council may modify it. Parliament negotiates with the Council and then votes on a resolution, by simple majority, on whether to accept the Council's decision. In practice, Parliament has had little influence on the main figures - for the CAP and structural spending but has used the opportunity to extract concessions concerning its own interests, e.g. the EP's influence in other areas.

The MYFP are then enshrined in an inter-institutional agreement that binds the Council, Commission and Parliament to "loyal cooperation" in yearly budgetary decisions, and notably to respect yearly expenditure ceilings.

It should be noted that these arrangements were never codified in any legal document establishing budgetary procedures. But this will change with the Reform Treaty's entry into force (see below).

This system has three main drawbacks. First, the yearly budget - which is the instrument with legal value under the Treaty - is not the real seat of budgetary decisions, which are made elsewhere. Second, the Council makes all significant decisions, outside the Community method and based on inter-governmental negotiations where every member state pursues mainly national interests and has veto power. Third, the MYFP are adopted for time periods that are completely disconnected with the time interval of legislatures and Commission tenure.

The Reform Treaty will at least impose legal clarity, but not much more. Under the Treaty, the MYFP will take the form of a Council Regulation, still decided by unanimity, after obtaining the Parliament's consent. The Commission still has no formal proposal role at this stage. However, on the positive side, the category of compulsory expenditures (i.e. mainly the CAP) has been suppressed, thus broadening the Parliament's vetting to include the entire yearly budget. 
Another beneficial change, which does not require a change in the Treaty, would be to synchronise the MYFP reference period with Parliament office terms, so as to strengthen the interrelation between budgetary decisions and European election results. The MYFP should run for five years, and enter into force one year after a new Parliament's election, to allow it sufficient time to deliberate after an election.

With this change, MYFP content would become a main theme in Parliament election campaigns, with a likely increase in voter interest in the elections and their results.

A new change in the Treaty will not be feasible until 2009. However, once it starts its own work on the new MYFP, the Parliament can already send the right political signals. It should tell the Council that it will accept whatever ceiling member states place on overall spending, but that it will expect to have a main say over the composition of spending and indicate what expenditures it considers a priority.

In this game of self-restraint, Parliament, by accepting the total expenditures ceiling, will gain credibility with governments and the electorate. In exchange, it will have affirmed its role in deciding what European public goods should come from the Union budget.

Box 1. Decisions, decisions...

Gros and Micossi (2005) argue that more radical change in decision-making would be even better:

"Clearly, the Union will not have a proper budget, as an expression of its priorities and policy goals, until both the MYFP and the yearly budget are decided by Community method, that is by co-decision of Council - deciding by majority vote - and Parliament, based on a legally binding Commission proposal. However, this decision-making power should not extend unchecked to the decision on the total resources ceiling, since the latter impinges on national parliaments' taxation powers. Moreover, the European Parliament is likely to have a bias in favour of more spending at the European level - even in areas where the greater European interest might best be served not by more spending at the EU level, but by other measures, for example increasing competition or coordination of national policies. A counterweight is thus needed.

One way to do this would be to leave the last word on total resources to the Council, but let the European Parliament determine their allocation across categories of spending. Such a distribution of competences is likely to lead to a useful implicit negotiation in which the allocation of spending proposed by the European Parliament would be accepted by the Council to the extent that it reflected European interests and 'value for money'. Were this not the case, the Council would reject the demands for a higher resource ceiling, and cut it to size."

\section{Concluding remarks}

Economists (and most other impartial observers) have criticised EU budget structure for over three decades. The main criticisms have remained the same: expenditure on agriculture, a declining industry, absorbs an inordinate budget share and re-distribution dominates the rest. Very little is spent in areas where one would expect real 'value added' from Union level spending. EU budget structure has been impervious to change while everything else has been changing profoundly, suggesting that the problem is not one of insufficient political will or lacking clear recognition of what is needed. The key reason must be a combination of decisionmaking mechanism and entrenched special interests. Both are unlikely to change in the near future, as farmers will continue to strongly defend their 'entitlement' to receive generous support, and as the Lisbon Reform Treaty did not - even though its crafters had the power to reform the decision-making mechanism. 
However, the forthcoming mid-term review should be seized to press for at least some marginal improvements. One important reason why it has been so difficult to reform the EU budget is that the requirement to reach unanimity has resulted in a very strong status quo bias, because decision-making rules imply that if no agreement is reached the appropriations foreseen for the last year of the previous framework will be continued. This has now been reinforced in the Reform Treaty, in which Art. 270a (4) explicitly reads:

4. Where no Council regulation determining a new financial framework has been adopted by the end of the previous financial framework, the ceilings and other provisions corresponding to the last year of that framework shall be extended until such time as that act is adopted.

This implies that any country that might be worse off under a reform that might benefit all others can simply exercise its veto. Any coalition of would-be reformers would thus have to buy off all potential opposition.

One way to reduce this status quo bias would be to introduce automatic 'sunset' clauses in all major expenditure programmes to ensure that an explicit agreement is required to continue them. At present an explicit agreement is required to curtail any expenditure. Sunset clauses should be required especially for the two major items that dominate the budget: spending on agriculture (CAP) and support for poorer regions (Structural Funds).

Regarding CAP, a soft sunset clause already exists in the sense that the Council agreed some time ago that CAP spending should increase less than nominal GDP, thus ensuring that over time the share of CAP spending in the overall EU budget should decline (provided, of course, the latter remains at around 1\% of GDP). The main problem here is that this rule imposes a rate of decline so low that it will take decades to have a noticeable effect. ${ }^{9}$

In principle, Structural Funds also have a sunset clause in the sense that only regions with a GDP per capital below $75 \%$ of the EU average are entitled to receive Structural Funds allocations. Most new member countries, which after an unavoidable transition period will obtain most Structural Funds, are now in an intense period of catching up to the EU average. However, it seems that some regions, especially those in relatively rich larger member states, never sufficiently catch up and thus never disqualify. It might thus be useful to introduce a rule specifying that no region should receive Structural Funds support for more than a certain fixed number of planning periods. Once this has passed, support would continue only if it could be shown that there were special reasons that did not allow the region in question to approach the EU average. The Commission should be tasked with drawing up a report on the use of the Structural Funds so far in the region(s) that failed to catch up and whether such special reasons exist.

It should be easier to reach agreement on sunset clauses than on an explicit agreement to lower expenditure today, because a sunset clause's impact is uncertain and lies in the future, thus generating much less opposition.

The EU budget has defied economic logic for decades and it is unlikely that this will change unless decision-making procedures radically change. Unfortunately, the Reform Treaty has only formalised current decision-making procedure and cemented its status quo bias. There is thus little reason to hope for substantial change from the mid-term budgetary review. However, some improvements for future budgets might still be possible if the status quo bias is lessened through appropriate sunset clauses.

\footnotetext{
${ }^{9}$ What is proposed here is essentially the opposite of the 2002 Franco-German agreement to protect CAP spending, which prejudged the current MYFP.
} 


\section{References}

Boldrin, M. and F. Canova (2001), "Inequality and convergence: Reconsidering European regional policies”, Economic Policy, No. 32.

Bottazzi, L. (2004), R\&D and the Financing of Ideas in Europe, CEPS Working Document No. 203, Centre for European Policy Studies, Brussels, October.

Buti, M. and M. Nava (2003), Towards a European Budgetary System, RSC No. 2003/08, Robert Schuman Centre for Advanced Studies, Florence.

Buti, M. and M. Nava (forthcoming), “'Constrained Flexibility’ as a Tool to Facilitate Reform of the EU Budget”, Public Finance and Management.

Cipriani, Gabriele (2007), Rethinking the EU Budget Three Unavoidable Reforms, Centre for European Policy Studies, CEPS Paperback, Brussels, December.

European Commission (2002), European Union public finance, Luxembourg. [Complete?]

European Commission (2004a), Financial Perspective 2007-2013, Communication from the Commission to the Council and the European Parliament, COM(2004) 487 final[, Brussels, date?].

European Commission (2004b), Financing the European Union, Commission report on the operation of the own resources system, COM(2004) 501 final[, Brussels, date?].

Goulard, S. and M. Nava (2002), Un financement plus démocratique du budget européen: un défi pour la Convention européenne, European Commission, mimeo[, Brussels, date?].

Gros, D. and S. Micossi (2005), A Better Budget for the European[“:”?] Union More Value for Money More Money for Value, Centre for European Policy Studies, CEPS Policy Brief No. 66, Brussels, February.

Gros, D. and J. Mortensen (2004), R\&D in the EU: Can the Open Method of Coordination Succeed in Closing the Gap?, Centre for European Policy Studies, CEPS Policy Brief No. 56, Brussels, July.

Heinemann, F. and M. Lefebvre (2005), La France, l'Allemagne et l'Europe. Perspectives (3). Réflexions franco-allemandes sur l'avenir du budget européen, les notes de l'ifri No. 57, Institut Français des Relations Internationales, Paris, January.

Mrak, M. and V. Rant (2008), "Financial Perspective 2007-2013: Domination of National Interests", unpublished manuscript, University of Ljubljana.

Núñez Ferrer, J. (2007), The EU Budget: The UK Rebate and the CAP Phasing them both out?, Centre for European Policy Studies, CEPS Task Force Report, Brussels, December.

Padoa-Schioppa, T. et al. (1987), Efficiency, stability and equity: A strategy for the evolution of the economic system of the EC, Report of a Study Group appointed by the Commission, Oxford: Oxford University Press.

Pelkmans, J. and J.P. Casey (2004), Can Europe deliver growth? The Sapir Report and Beyond, CEPS Policy Brief No. 45, Centre for European Policy Studies, Brussels, January.

Sapir, A. et al. (2003), An Agenda for a Growing Europe: Making the EU System Deliver, Report of an Independent High-Level Group established at the initiative of the President of the European Commission, Oxford: Oxford University Press.

Tabellini, G. (2002), The Assignment of Tasks in an Evolving European Union, CEPS Policy Brief No. 10, Centre for European Policy Studies, Brussels, January. 


\section{Annex 1. Limits on CAP spending}

\section{Excerpt 1.}

Berlin European Council 1999 (Financial Perspective to 2007)

\section{Heading 1 (Agriculture)}

Agricultural guideline. Overall level of allocations for heading 1

23. In light of these decisions, the European Council considers that the amounts to be entered in heading 1 of the financial perspective should not exceed:

\begin{tabular}{|c|c|c|c|c|c|c|}
\hline \multicolumn{7}{|c|}{ Heading 1 (Agriculture) (Mio. euros 1999 prices) } \\
\hline 2000 & 2001 & 2002 & 2003 & 2004 & 2005 & $\underline{2006}$ \\
\hline 40,920 & 42,800 & 43,900 & 43,770 & 42,760 & 41,930 & $\underline{41,660}$ \\
\hline \multicolumn{7}{|c|}{ CAP expenditure (excluding rural development and accompanying measures) } \\
\hline 36,620 & 38,480 & 39,570 & 39,430 & 38,410 & 37,570 & 37,290 \\
\hline \multicolumn{7}{|c|}{ Rural development and accompanying measures } \\
\hline 4,300 & 4,320 & 4,330 & 4,340 & 4,350 & 4,360 & 4,370 \\
\hline
\end{tabular}

The inter-institutional agreement should include a provision ensuring that all parties to it will respect the financial perspective ceiling for agriculture.

\section{Excerpt 2.}

Brussels European Council October 2002 (Doc. 14702/02 5)

Budgetary and financial issues (2004-06)

10. The ceiling for enlargement-related expenditure established for the years 2004-06 by the European Council in Berlin must be respected.

11. The Union's expenditure must continue to respect both the imperative of budgetary discipline and efficient expenditure, and the need to ensure that the enlarged Union has sufficient resources to ensure the orderly development of its policies for the benefit of all its citizens. 
The phasing-in will take place within a framework of financial stability, where total annual expenditure for market-related expenditure and direct payments in a Union of 25 cannot, in the period 2007-13, exceed the amount in real terms of the ceiling of category 1.A for 2006 agreed in Berlin for the EU-15 and the proposed corresponding expenditure ceiling for the new member states for 2006. The overall expenditure in nominal terms for market-related expenditure and direct payments for each year in the period 2007-13 shall be kept below this 2006 figure and increased by $1 \%$ per year.

\section{Excerpt 3.}

Copenhagen European Council December 2002 (Doc. 15917/02 12)

\section{ANNEX I \\ BUDGETARY AND FINANCIAL ISSUES}

Based on the accession of ten new member states by 1 May 2004, the maximum appropriations for commitments for agriculture, structural operations, internal policies and administration for new member states should be the amounts now determined as a result of the negotiations at this European Council, as set out in the following table:

This is without prejudice to the EU 25 ceiling for category 1a for 2007-13 established by the Decision of the Representatives of the Governments of the Member States, meeting within the Council on 14 November 2002, concerning the conclusions of the European Council meeting in Brussels on 24 and 25 October 2002. 


\section{Annex 2. Budgetary provisions in the Reform Treaty}

\section{The MYFP are integrated into the Treaty:}

\section{Multiannual financial framework}

261) The following new Chapter 2 and new Art. 270a shall be inserted:

\section{“CHAPTER 2 THE MULTIANNUAL FINANCIAL FRAMEWORK}

Article 270a

1. The multiannual financial framework shall ensure that Union expenditure develops in an orderly manner and within the limits of its own resources.

It shall be established for a period of at least five years.

The annual budget of the Union shall comply with the multiannual financial framework.

2. The Council, acting in accordance with a special legislative procedure, shall adopt a regulation laying down the multiannual financial framework. The Council shall act unanimously after obtaining the consent of the European Parliament, which shall be given by a majority of its component members.

The European Council may, unanimously, adopt a decision authorising the Council to act by a qualified majority when adopting the regulation referred to in the first paragraph.

3. The financial framework shall determine the amounts of the annual ceilings on commitment appropriations by category of expenditure and of the annual ceiling on payment appropriations. The categories of expenditure, limited in number, shall correspond to the Union's major sectors of activity.

The financial framework shall lay down any other provisions required for the annual budgetary procedure to run smoothly.

4. Where no Council regulation determining a new financial framework has been adopted by the end of the previous financial framework, the ceilings and other provisions corresponding to the last year of that framework shall be extended until such time as that act is adopted.

5. Throughout the procedure leading to the adoption of the financial framework, the European Parliament, the Council and the Commission shall take any measure necessary to facilitate its adoption.” 


\section{Application of Community method to the annual budget}

\section{The Union's annual budget}

262) A Chapter 3 “THE UNION’S ANNUAL BUDGET” shall be inserted after Art. 270a.

263) An Art. 270b shall be inserted, with the wording of Art. 272(1).

264) Art. 271 shall become the new Art. 273a; it shall be amended as set out below in point 267 .

265) Art. 272(1) shall become Art. 270b and paragraphs 2 to 10 shall be replaced by the following:

"The European Parliament and the Council, acting in accordance with a special legislative procedure, shall establish the Union's annual budget in accordance with the following provisions.

1. With the exception of the European Central Bank, each institution shall, before 1 July, draw up estimates of its expenditure for the following financial year. The Commission shall consolidate these estimates in a draft budget which may contain different estimates.

The draft budget shall contain an estimate of revenue and an estimate of expenditure.

2. The Commission shall submit a proposal containing the draft budget to the European Parliament and to the Council not later than 1 September of the year preceding that in which the budget is to be implemented.

The Commission may amend the draft budget during the procedure until such time as the Conciliation Committee, referred to in paragraph 5, is convened.

3. The Council shall adopt its position on the draft budget and forward it to the European Parliament not later than 1 October of the year preceding that in which the budget is to be implemented. The Council shall inform the European Parliament in full of the reasons which led it to adopt its position.

4. If, within forty-two days of such communication, the European Parliament:

(a) approves the position of the Council, the budget shall be adopted;

(b) has not taken a decision, the budget shall be deemed to have been adopted;

(c) adopts amendments by a majority of its component members, the amended draft shall be forwarded to the Council and to the Commission. The President of the European Parliament, in agreement with the President of the Council, shall immediately convene a meeting of the Conciliation Committee. However, if within ten days of the draft being forwarded the Council informs the European Parliament that it has approved all its amendments, the Conciliation Committee shall not meet.

5. The Conciliation Committee, which shall be composed of the members of the Council or their representatives and an equal number of members representing the European Parliament, shall have the task of reaching agreement on a joint text, by a qualified majority of the members of the Council or their representatives and by a majority of the representatives of the European Parliament within twenty-one days 
of its being convened, on the basis of the positions of the European Parliament and the Council.

The Commission shall take part in the Conciliation Committee's proceedings and shall take all the necessary initiatives with a view to reconciling the positions of the European Parliament and the Council.

6. If, within the twenty-one days referred to in paragraph 5, the Conciliation Committee agrees on a joint text, the European Parliament and the Council shall each have a period of fourteen days from the date of that agreement in which to approve the joint text.

7. If, within the period of fourteen days referred to in paragraph 6:

(a) the European Parliament and the Council both approve the joint text or fail to take a decision, or if one of these institutions approves the joint text while the other one fails to take a decision, the budget shall be deemed to be definitively adopted in accordance with the joint text; or

(b) the European Parliament, acting by a majority of its component members, and the Council both reject the joint text, or if one of these institutions rejects the joint text while the other one fails to take a decision, a new draft budget shall be submitted by the Commission; or

(c) the European Parliament, acting by a majority of its component members, rejects the joint text while the Council approves it, a new draft budget shall be submitted by the Commission; or

(d) the European Parliament approves the joint text whilst the Council rejects it, the European Parliament may, within fourteen days from the date of the rejection by the Council and acting by a majority of its component members and three-fifths of the votes cast, decide to confirm all or some of the amendments referred to in paragraph 4(c). Where a European Parliament amendment is not confirmed, the position agreed in the Conciliation committee on the budget heading which is the subject of the amendment shall be retained. The budget shall be deemed to be definitively adopted on this basis.

8. If, within the twenty-one days referred to in paragraph 5, the Conciliation Committee does not agree on a joint text, a new draft budget shall be submitted by the Commission.

9. When the procedure provided for in this Article has been completed, the President of the European Parliament shall declare that the budget has been definitively adopted.

10. Each institution shall exercise the powers conferred upon it under this Article in compliance with the Treaties and the acts adopted thereunder, with particular regard to the Union's own resources and the balance between revenue and expenditure." 


\section{About CEPS}

Founded in Brussels in 1983, the Centre for European Policy Studies (CEPS) is among the most experienced and authoritative think tanks operating in the European Union today. CEPS serves as a leading forum for debate on EU affairs, but its most distinguishing feature lies in its strong in-house research capacity, complemented by an extensive network of partner institutes throughout the world.

\section{Goals}

- To carry out state-of-the-art policy research leading to solutions to the challenges facing Europe today.

- To achieve high standards of academic excellence and maintain unqualified independence.

- To provide a forum for discussion among all stakeholders in the European policy process.

- To build collaborative networks of researchers, policy-makers and business representatives across the whole of Europe.

- To disseminate our findings and views through a regular flow of publications and public events.

\section{Assets}

- Complete independence to set its own research priorities and freedom from any outside influence.

- Formation of nine different research networks, comprising research institutes from throughout Europe and beyond, to complement and consolidate CEPS research expertise and to greatly extend its outreach.

- An extensive membership base of some 120 Corporate Members and 130 Institutional Members, which provide expertise and practical experience and act as a sounding board for the utility and feasability of CEPS policy proposals.

\section{CEPS carries out its research via its own in-house} research programmes and through collaborative research networks involving the active participation of other highly reputable institutes and specialists.

\section{Research Programmes}

Economic \& Social Welfare Policies

Energy, Climate Change \& Sustainable Development

EU Neighbourhood, Foreign \& Security Policy

Financial Markets \& Taxation

Justice \& Home Affairs

Politics \& European Institutions

Regulatory Affairs

Trade, Development \& Agricultural Policy

\section{Research Networks/Joint Initiatives}

Changing Landscape of Security \& Liberty (CHALLENGE)

European Capital Markets Institute (ECMI)

European Climate Platform (ECP)

European Credit Research Institute (ECRI)

European Network of Agricultural \& Rural Policy Research Institutes (ENARPRI)

European Network for Better Regulation (ENBR)

European Network of Economic Policy Research Institutes (ENEPRI)

European Policy Institutes Network (EPIN)

European Security Forum (ESF)

CEPS also organises a variety of activities and special events, involving its members and other stakeholders in the European policy debate, national and EU-level policy-makers, academics, corporate executives, NGOs and the media. CEPS' funding is obtained from a variety of sources, including membership fees, project research, foundation grants, conferences fees, publication sales and an annual grant from the European Commission.

E-mail: info@ceps.be

Website: http://www.ceps.be

Bookshop: http://shop.ceps.be 